\title{
Allelopathic activity of Dendrophthoe pentandra as a potential bioherbicide to inhibit seed germination and seedling growth of Eleusine indica
}

\author{
LUTFAN ALHARITS ${ }^{1}$, NIARSI MERRY HEMELDA ${ }^{1,2, \boldsymbol{v}}$, YASMAN ${ }^{1,2}$, WINDRI HANDAYANI ${ }^{1,2}$ \\ ${ }^{1}$ Department of Biology, Faculty of Mathematics and Natural Sciences, Universitas Indonesia. Kampus UI, Depok 16424, West Java, Indonesia. \\ ${ }^{2}$ Research Group of Metabolomics and Chemical Ecology, Department of Biology, Faculty of Mathematics and Natural Sciences, Universitas Indonesia. \\ Kampus UI, Depok 16424, West Java, Indonesia. Tel.: +62-21-7863436, 7863437 Fax.: +62-21-7270012, `email: merry.hemelda@ sci.ui.ac.id
}

Manuscript received: 6 November 2019. Revision accepted: 29 January 2020.

\begin{abstract}
Alharits L, Hemelda NM, Yasman, Handayani W. 2020. Allelopathic activity of Dendrophthoe pentandra as a potential bioherbicide to inhibit seed germination and seedling growth of Eleusine indica. Nusantara Bioscience 12: 33-39. Dendrophthoe pentandra (L.) Miq. is a common parasitic plant in Southeast Asia. As a parasitic plant, it exhibits phytochemicals important for infecting its host, which may be potential as bioherbicide. This study was aimed to evaluate allelopathic activity of D. pentandra (stem and leaf extracts) to control Eleusine indica (L.) Gaertn. seed germination and growth. Methanolic extracts of D. pentandra stem and leaf $(0,1,2,3,4$ and $5 \mathrm{mg} / \mathrm{mL}$ in water) were treated on $E$. indica seeds in a petri dish for 10 days. After 10 days, germination of treated $E$. indica seeds was significantly reduced and reached $>80 \%$ inhibition at $5 \mathrm{mg} / \mathrm{mL}$. Moreover, E. indica roots were more sensitive compared to E. indica shoots, indicated by root inhibition $>50 \%$ at $1 \mathrm{mg} / \mathrm{mL}$ and reached $>90 \%$ inhibition at $5 \mathrm{mg} / \mathrm{mL}$. Leaf extract presented stronger inhibition than stem extract, but not significant. It may be related to the higher accumulation of phenolic and flavonoid compounds in leaf extract than in stem extract. This is the first report of allelopathic activity in $D$. pentandra to inhibit $E$. indica germination and growth. Therefore, further study in a greenhouse, as well as metabolism effects of $D$. pentandra on the target weeds are important to provide comprehensive evaluation of $D$. pentandra potential as bioherbicide.
\end{abstract}

Keywords: Allelopathic activity, bioherbicide, Dendrophthoe pentandra, Eleusine indica, phytochemicals

\section{INTRODUCTION}

Weeds are one of the problematic issues in agriculture. Weeds are responsible for crop yield loss because they compete with the crop plants, harbor pests, and reduce the seed crop quality (Zimdahl 2007). In India, weeds are reported responsible for economic losses about USD 4420 million only from rice yield loss (Gharde et al. 2018). Synthetic herbicides are often selected as the solution in controlling weeds. However, their long term usage brings adverse effects on both human and environment (Qasem 2011).

For those reasons, bioherbicides are considered as an alternative solution to reduce the use of synthetic herbicides. As bioherbicides contain natural compounds, they are harmless to both human and environment (Dayan and Duke 2014). One of the potential sources for bioherbicidal compounds comes from plants. Plants produce allelochemicals, such as phenols, tannins, (Zaidi et al. 2008), alkaloids, saponins (Widiyastuti et al. 2011), terpenoids, flavonoids (Shaikh et al. 2016), and coumaric acid (Selvi et al. 2018). Those compounds are reported to have herbicidal traits, such as able to inhibit cell division (Soltys et al. 2011) and decrease photosynthetic rate of other plants (Chen et al. 2018).

Dendrophthtoe pentandra (L.) Miq. is a common parasitic plant in Southeast Asia (Giesen et al. 2006) with broad spectrum of host plants (Sunaryo 2008). Despite being an undesirable plant, $D$. pentandra is reported containing many potential biocompounds, such as alkaloids, flavonoids, saponins and triterpenoids (Fitrilia et al. 2015), also exhibits many bioactivity, such as antioxidant (Fitrilia et al. 2015), anti-diabetic (Fitrilia et al. 2017), anti-bacteria (Anita et al. 2014) and anti-cancer (Yee et al. 2017). Based on its chemical contents, there is a possibility that $D$. pentandra is potential for bioherbicide.

There is no information yet about $D$. pentandra allelopathic activity. However, some of parasitic plants are reported possessing allelopathic or herbicidal activity (Zaidi et al. 2008; Othman et al. 2012; Sumariono et al. 2016), including one of $D$. pentandra related species, $D$. falcata (Priya and Neelamegam 2016). Moreover, like any other parasitic plants, D. pentandra branch clusters along with the infected host branches are often pruned to remove them from the host trees (Lichter et al. 1991; Maffei et al. 2016). They were then treated as less economically valuable organic trashes for mulch or compost production (Watson 2018). Such condition provides abundant sources of $D$. pentandra that would be perfect for $D$. pentandra utilization as bioherbicide.

Therefore, this study was aimed to evaluate the allelopathic activity of $D$. pentandra stem and leaf extract to control weeds germination and growth. In this study, Eleusine indica (L.) Gaertn. was selected as the weeds model because $E$. indica has been known to disturb many important crops such as soybean, rice, and corn (Sandoval 
and Rodriguez 2014). This study was also expected to be a preliminary study of $D$. pentandra application as a potential bioherbicide.

\section{MATERIALS AND METHODS}

\section{Plant materials}

Dendrophthoe pentandra stem and leaf simplicia collected in August 2018 were used in this study. Leaves and tender stems of $D$. pentandra were collected from a Bauhinia purpurea host tree in Universitas Indonesia campus, Depok, West Java. All collected leaves were green and did not show any disease symptoms or herbivore bites, and only mature leaves were collected. All collected stems were tender and green, but brownish stems with hard skin were excluded. Eleusine indica was also collected from Universitas Indonesia campus, Depok, West Java. Only inflorescences with mature seeds were collected for germination test. For identification, a $D$. pentandra branch with leaves and inflorescences, and a whole plant of $E$. indica were sent to the Indonesian Institute of Sciences.

\section{Experimental design}

This study used completely randomized design with two independent variables: (i) extract sources (stem and leaf), and (ii) concentration series of $1,2,3,4$, and 5 $\mathrm{mg} / \mathrm{mL}$ of each extract, and three dependent variables: (i) seed germination, (ii) shoot length, and (iii) root length. There were total 12 treatment groups, including five groups treated with various concentrations of stem extract (S1, S2, $\mathrm{S} 3$, S4, and S5), five groups treated with various concentrations of leaf extract (L1, L2, L3, L4, and L5), one group of negative control (NC), and one group treated with herbicide (Calaris) (H). Each treatment group was performed on three petri dishes consisted of 90 seeds of $E$. indica.

\section{Procedures}

Sample preparation and extraction

Dendrophthoe pentandra stems and leaves simplicia were grounded and filtered through T32 mesh filter to produce uniform-sized powder. The powder was then extracted by maceration method (Ncube et al. 2008). A total of $50 \mathrm{~g}$ powder of each organ was extracted in $1 \mathrm{~L}$ of methanol for 3 times in 72 hours. The mixture was filtered and evaporated using rotary evaporator to obtain the crude extract. Extract was then dried inside the oven at $40^{\circ} \mathrm{C}$ until they reached constant weight indicating that the extract was free from the organic solvent. Both of the extracts were used for allelopathic activity assay and quantitative phytochemical measurements.

\section{Eleusine indica seed pretreatment}

Eleusine indica seeds were peeled by rubbing them with hands gently. After the seed coats were completely removed, the seeds were tested for their viability according to Kanzler and Van Staden (1984) with some modifications. Briefly, seeds were immersed in $1 \%$ of $2,3,5$ triphenyltetrazolium chloride for 24 hours in dark conditions. Seeds that turned into pink or red were considered viable and selected for the next step. Viable seeds were soaked in sterile distilled water for 24 hours for imbibition, followed by surface sterilization step using $5.25 \%$ natrium hypochlorite $(\mathrm{NaClO})$ solution for 10 minutes. Sterile seeds were rinsed with sterile distilled water 4 times to clean the seeds from $\mathrm{NaClO}$ residue. Then, seeds were dried at room temperature for 1 hour before proceeded for allelopathic activity assay.

\section{Allelopathic activity assay}

Allelopathic activity assay was carried out using petri dish assay method according to Taban and Saharkhiz (2015) with some modifications. Briefly, D. pentandra stem and leaf methanolic extracts were re-diluted in sterile distilled water into various concentrations (1, 2, 3, 4 and 5 $\mathrm{mg} / \mathrm{mL}$ ) until they reached homogenous condition. A total of 30 viable and sterile seeds of E. indica were placed on two layers of filter paper no. 100 in a $9-\mathrm{cm}$ diameter petri dish. Then, $5 \mathrm{~mL}$ of each extract concentration was added carefully to the filter paper. Petri dish was sealed with parafilm to prevent volatile compounds escape from the petri dish. For negative control, $5 \mathrm{~mL}$ of sterile distilled water was used to substitute the extract. Meanwhile, for positive control, $5 \mathrm{~mL}$ of $0.47 \%$ herbicide Calaris was used instead of the extract. Each treatment was carried out in three petri dishes.

Petri dishes were incubated at growth chamber for 10 days with temperature between $18^{\circ} \mathrm{C}$ to $28^{\circ} \mathrm{C}, 3350$ lux light, and 12 hours photoperiodism. Germinated seeds were observed daily. At the end of incubation, total seed germination, shoot length, and root length was measured. Only seeds emerging $\geq 2 \mathrm{~mm}$ of embryo were considered germinated (Tobe et al. 2000).

\section{Total phenolic and flavonoid contents}

To investigate the phenolic and flavonoid contents of stem and leaf extracts of $D$. pentandra, total phenolic content (TPC) and total flavonoid content (TFC) analysis were carried out. Follin-Ciocalteu reagent assay was performed for TPC measurement (Al-Matani et al. 2015) with some modifications. Briefly, gallic acid (GA) standard solutions $(12.5,25,50,100$ and $200 \mathrm{ppm})$ were prepared for GA standard curve. Then, each of stem and leaf crude extracts $(10 \mathrm{mg})$ was diluted in $10 \mathrm{~mL}$ of pro analysis methanol. Approximately $0.2 \mathrm{~mL}$ of extract solution or standard solution was placed in a $15 \mathrm{~mL}$ test tube. After that, $1.8 \mathrm{~mL}$ distilled water and $0.1 \mathrm{~mL}$ Follin-Ciocalteu reagent were mixed to each solution. All solutions were homogenized and incubated in dark conditions for 5 minutes. Then, $1 \mathrm{~mL} \mathrm{Na} \mathrm{CO}_{3} 5 \%$ was added to each mixture and homogenized with vortex. The mixture was then diluted with water to reach $5 \mathrm{~mL}$ of solution volume. The mixture was incubated in dark conditions for 60 minutes. The absorbance of extract and standard solutions were examined against a reagent blank by Uv-Visible spectrophotometer at $750 \mathrm{~nm}$. Each of the standard concentrations and extracts was performed in triplicate. The total phenolic content of $D$. pentandra stem and leaf extracts were expressed in Gallic Acid Equivalent 
(GAE)/100g.

The $\mathrm{AlCl}_{3}$ assay was performed for TFC analysis according to Al-Matani et al. (2015) with some modifications. Briefly, quercetin (Q) standard solutions $(12.5,25,50,100$ and $200 \mathrm{ppm})$ were prepared for Q standard curve. Each stem and leaf crude extract $(10 \mathrm{mg})$ was diluted in $10 \mathrm{~mL}$ of pro analysis methanol. Approximately $0.25 \mathrm{~mL}$ of extract solution or standard solution was placed in a $15 \mathrm{~mL}$ test tube. After that, 1.25 $\mathrm{mL}$ distilled water and $75 \mu \mathrm{L}$ of $\mathrm{NaNO}_{3} 5 \%$ solution were mixed to each solution. All solutions were homogenized with vortex and incubated in dark conditions for 6 minutes. Then, $150 \mu \mathrm{L} \mathrm{AlCl} \mathrm{Al}_{3} 10 \%$ solution was added to each mixture. All mixtures were incubated in dark conditions for 5 minutes. Each mixture was added with $0.5 \mathrm{~mL} \mathrm{NaOH} 4 \%$ solution and $275 \mu \mathrm{L}$ distilled water. The mixtures were mixed well and the absorbance of each mixture was examined against a reagent blank with UV-Visible spectrophotometer at $510 \mathrm{~nm}$. Each of the standard concentrations and extracts was performed in triplicate. The total flavonoid content of $D$. pentandra stem and leaf extracts were expressed in Quercetin Equivalent $(\mathrm{QE}) / 100 \mathrm{~g}$.

\section{Data analysis}

Germination and seedling growth data were tabulated at an examination sheet. Then, the data were analyzed with one-way analysis of variance (ANOVA) test $(p<0.01)$. After that, the means values were compared with LSD test as a post hoc analysis. All statistical analysis was performed using SPSS software ver. 21.

\section{RESULTS AND DISCUSSION}

\section{Allelopathic activity of Dendrophthoe pentandra extracts inhibiting Eleusine indica seed germination}

Allelopathic activity of $D$. pentandra stem and leaf extracts were evaluated based on its ability to inhibit the germination of $E$. indica. Both of the extracts showed a concentration-dependent germination inhibition. The germination inhibition was higher gradually along with the application of higher concentration. Germination of $E$. indica seeds was reduced by more than $50 \%$ when treated with $\geq 3 \mathrm{mg} / \mathrm{mL}$ of either stem or leaf extract. Moreover, treatment of $\geq 4 \mathrm{mg} / \mathrm{mL}$ of leaf extract were able to reduce the germination of more than $90 \%$ (Figure 1.A).

Stem extract significantly reduced the germination of $E$. indica seeds in the lowest concentration of each extract (1 $\mathrm{mg} / \mathrm{mL}$ ) while leaf extract presented significant reduction of $E$. indica seed germination from $2 \mathrm{mg} / \mathrm{mL}$. Both of the extracts presented stronger inhibition in higher concentrations (4 and $5 \mathrm{mg} / \mathrm{mL}$ ) compared to those in low concentrations (1 and $2 \mathrm{mg} / \mathrm{mL}$ ). In addition, high concentration treatment tended to presented similar inhibition levels with herbicidal treatment. Leaf extract was observed to give similar inhibition effects with herbicidal treatment at 4 and $5 \mathrm{mg} / \mathrm{mL}$. However, on stem extract, such inhibition was only observed at $5 \mathrm{mg} / \mathrm{mL}$ (Figure 1BC).

To investigate whether the extract sources (stem or leaf) affected the germination inhibition of $E$. indica seeds, oneway ANOVA was performed to compare the means of germination of seeds treated with both extracts on each concentration. The result showed that germination of seeds treated with stem and leaf extracts did not differ significantly on each concentration (Figure 1D). However, leaf extract was able to inhibit more seeds than stem extract.

\section{Effect of Dendrophthoe pentandra extracts on Eleusine indica seedling growth}

Dendrophthoe pentandra extract treatments did not only inhibit the germination of Eleusine indica, but also affected the morphology of the seedlings. Based on morphological observation, seeds treated with both of the extracts appeared to germinate and grow shorter shoots and roots compared to those of negative control treatment (Table 1). In addition, the color of roots changed from white to brownish, and appeared darker along with the higher concentration. In high concentrations, the roots were even dried and fragile. Similar changes were also observed in roots of seedlings treated with herbicide.

However, we did not observe any changes in the shoot color of extract-treated seedlings. Even though the length of the shoots tended to be shorter, the color still appeared green, similar to the shoots of negative control seedlings. On the contrary, in herbicidal treated seedlings, all of the seedlings were observed having white-colored shoots.

To investigate the effect of $D$. pentandra stem and leaf extracts on seedling growth of $E$. indica, one-way ANOVA followed by LSD test was performed on the root and shoot length of treated seedlings and negative control seedlings. However, only negative control seedlings and seedlings treated with 1 and $2 \mathrm{mg} / \mathrm{mL}$ of each extract were compared. Seedlings treated with 3,4 and $5 \mathrm{mg} / \mathrm{mL}$ of each extract were excluded because of fewer seedlings available for those concentrations.

Stem and leaf extract treatments were observed to inhibit shoot and root growth of $E$. indica seedlings. Based on LSD test, D. pentandra stem and leaf extract did not significantly affect the shoot growth at $1 \mathrm{mg} / \mathrm{mL}$ concentration, even though the shoot growth was reduced for more than $10 \%$ inhibition in treated seedlings. At 2 $\mathrm{mg} / \mathrm{mL}$ concentration, leaf extract affected shoot growth significantly while stem extract did not. Meanwhile, stem and leaf extract treatments were able to significantly inhibit the root growth for more than $50 \%$ inhibition at the lowest concentration. However, the effect of both stem and leaf extract treatments was not significant between $1 \mathrm{mg} / \mathrm{mL}$ and $2 \mathrm{mg} / \mathrm{mL}$ (Figure 2A-B). The effect of both extracts was continuously stronger as the treatment concentrations were higher. 

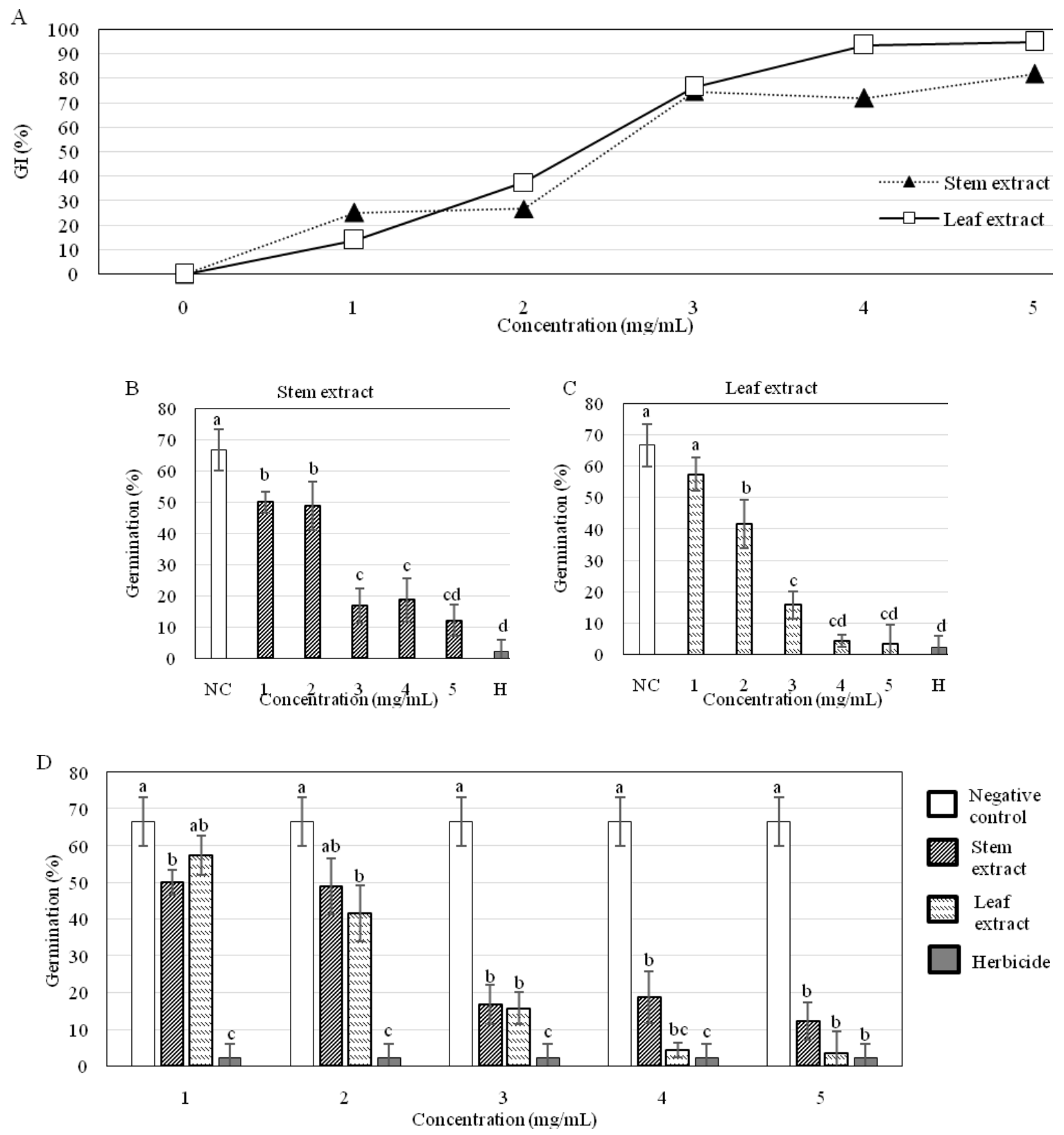

Figure 1. Germination of E. indica seeds. Germination inhibition (A), germination of seeds treated with stem extract (B), germination of seeds treated with leaf extract (C), and comparison between germination of seeds treated with stem and leaf extracts in each concentration (D). NC, negative control; $\mathrm{H}$, herbicide. One-way ANOVA followed by LSD test, $\mathrm{p}<0.01$ was used to determine the significant differences between groups

To investigate whether the extract sources (stem and leaf) affected the growth inhibition level, one-way ANOVA followed by LSD test was performed on the three groups: water treatment (negative control), stem extract treatments, and leaf extract treatments on each concentration of $1 \mathrm{mg} / \mathrm{mL}$ and $2 \mathrm{mg} / \mathrm{mL}$. Both of the extracts presented similar power of inhibition at concentration of 1 and $2 \mathrm{mg} / \mathrm{mL}$, in both shoot and root growth (Figure 2C-D).

\section{Phenolic and flavonoid contents of Dendrophthoe pentandra}

As phenolic and flavonoid compounds are often related to the bioactivity of a plant, the total phenolic and flavonoid contents were investigated in stem and leaf extract of $D$. pentandra. Based on TPC and TFC analysis, both of the stem and leaf extracts contained similar content of phenolic and flavonoid extract. However, leaf extract presented higher in both phenolic and flavonoid content (Table 2). 
Table 1. Morphological measurement of Eleusine indica seedling growth

\begin{tabular}{lcccccc}
\hline \multirow{2}{*}{ Treatment } & \multirow{2}{*}{$\begin{array}{c}\text { Concentration } \\
(\mathbf{m g} / \mathbf{m L})\end{array}$} & $\begin{array}{c}\text { Number of } \\
\text { seedlings }\end{array}$ & \multicolumn{2}{c}{ Shoot } & \multicolumn{2}{c}{ Root } \\
\cline { 4 - 7 } & N/A & 60 & $6.90 \pm 2.22$ & 0.00 & $10.77 \pm 5.65$ & 0.00 \\
Negative control & 1 & 45 & $6.03 \pm 2.14$ & 12.64 & $3.42 \pm 2.17$ & 68.26 \\
Stem extract & 2 & 44 & $5.24 \pm 1.75$ & 24.05 & $3.04 \pm 2.07$ & 71.81 \\
& 3 & 15 & $3.83 \pm 1.85$ & 44.44 & $1.63 \pm 1.72$ & 84.83 \\
& 4 & 16 & $2.86 \pm 0.78$ & 58.54 & $0.72 \pm 0.55$ & 93.36 \\
Leaf extract & 5 & 11 & $2.35 \pm 0.93$ & 65.96 & $0.74 \pm 0.33$ & 93.12 \\
& 1 & 50 & $6.01 \pm 1.85$ & 12.97 & $4.42 \pm 1.56$ & 58.94 \\
& 2 & 37 & $4.07 \pm 2.00$ & 41.00 & $2.71 \pm 2.13$ & 74.88 \\
& 3 & 14 & $3.84 \pm 1.59$ & 44.36 & $2.33 \pm 1.77$ & 78.38 \\
Herbicide & 4 & 4 & $2.56 \pm 1.02$ & 62.93 & $0.84 \pm 0.10$ & 92.16 \\
\hline N & 5 & 3 & $2.36 \pm 0.99$ & 65.76 & $0.40 \pm 0.36$ & 96.33 \\
& $0.47 \%$ & 2 & $4.42 \pm 1.63$ & 35.89 & $0.74(0.07$ & 93.12 \\
\hline
\end{tabular}

Note: N/A, not available; *Percentage of inhibition was calculated over negative control values.

Table 2. Total phenolic and flavonoid contents of Dendrophthoe pentandra stem and leaf extracts

\begin{tabular}{lcc}
\hline Extract sources & Total phenolic content $(\mathbf{m g ~ G A E} / \mathbf{g})$ & Total flavonoid content $(\mathbf{m g}$ QE/g) \\
\hline Leaf & $35.68 \pm 0.51$ & $113.27 \pm 4.04$ \\
Stem & $31.22 \pm 0.74$ & $98.27 \pm 7.51$ \\
\hline
\end{tabular}

Note: GAE, gallic acid equivalent; QE, quercetin equivalent
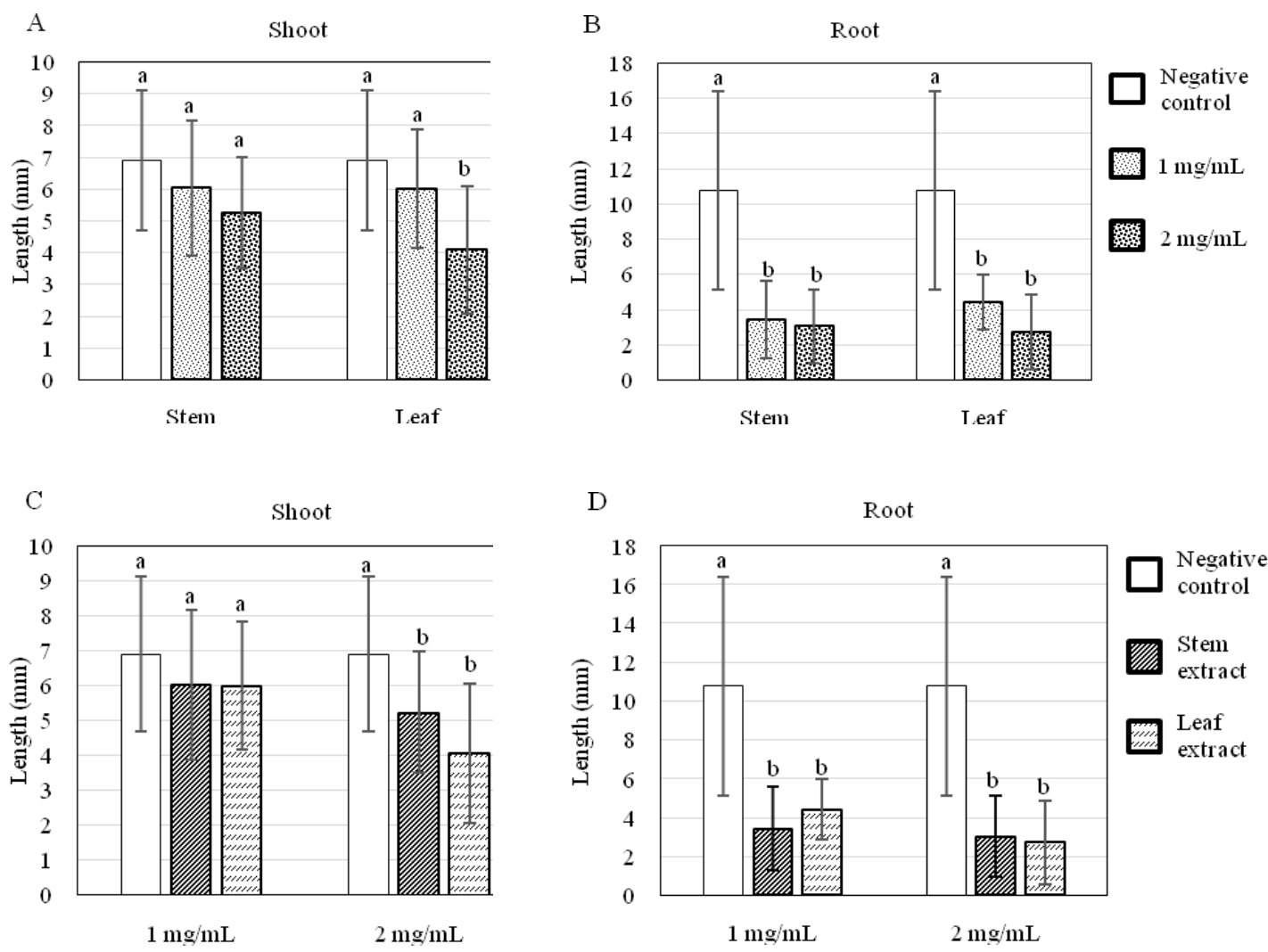

Figure 2. Dendrophthoe pentandra extracts effect on Eleusine indica seedlings growth. Graphs are presented based on the extract sources (A-B), and each concentration (C-D). One-way ANOVA followed by LSD test, $\mathrm{p} \leq 0.01$ was used to determine the significant differences between groups 


\section{Discussion}

Dendrophthoe pentandra stem and leaf extracts were confirmed to have allopathic activity in this study, because they were able to inhibit seed germination and seedling growth of Eleusine indica. Allelochemicals of $D$. pentandra may be responsible for inhibition of germination and growth. Allelochemicals are reported to affect important physiological processes in germination. Nicotiana plumbaginifolia leachate was reported to decrease the relative water content, giving the effect of water stress on Zea mays seedlings (Singh et al. 2009). Moreover, allelochemicals are able to reduce the activity of enzymes which are important for germination. Eupatorium odoratum and Beta vulgaris extracts are able to reduce amylase activity which is important in hydrolyzing endospermic starch into maltose (Hegab et al. 2008; Madane and Patil 2017). As the starch is hydrolyzed slowly because of amylase degradation, germination process will be delayed (Joshi 2018; Radhakrishnan et al. 2018).

Many works have been established in plant extract utilization to inhibit $E$. indica seed germination. Capsicum annuum water extract was reported to inhibit $100 \%$ of $E$. indica seed at $20 \mathrm{mg} / \mathrm{mL}$ (Chuah et al. 2011), Mucuna bracteata leaf water extract inhibited $62.5 \%$ at $16.7 \mathrm{mg} / \mathrm{mL}$ (Halimshah et al. 2015), and Pueraria javanica leaf water extract inhibited $70 \%$ at $16.7 \mathrm{mg} / \mathrm{mL}$. Compared to those plants, D. pentandra methanolic extract presented higher inhibition $(>80 \%$ at $5 \mathrm{mg} / \mathrm{mL}$ ). However, the solvent used for extraction may also affect the level of bioactivity of a plant extract. Methanol as a solvent is able to extract more phenolic and flavonoid compounds than water (Do et al. 2013).

Beside inhibiting germination process of $E$. indica, $D$. pentandra extracts also inhibited the seedling growth. Eleusine indica roots were more sensitive to the extract treatments than shoots. Treatment with the lowest concentration inhibited the root growth by more than $50 \%$. Similar result was also observed in Xanthium strumarium extract inhibiting the cell division and elongation process of root apical part (Mukherjee and Dalal 2015). Cell mitosis inhibition and abnormalities mitosis in root also observed on Allium cepa root treated by Aglaia odorata ethyl acetate fraction which disrupted chromatin organization and mitotic spindle (Teerarak et al. 2012).

Stem and leaf extracts of $D$. pentandra presented similar power in inhibiting seed germination and seedling growth of $E$. indica even though leaf extract showed greater inhibition than stem extract. Several studies also obtained similar results, such as in Melilotus indicus (Mousavi et al. 2013) and Achillea bieberstenii (Romman 2016), that leaf extract gave more inhibition effect than stem extract. This different level of inhibition may be related to accumulation of phytochemical compounds in leaves. Leaves often accumulate more secondary metabolites than stems (Chon et al. 2006). The accumulation of certain secondary metabolites such as flavonoids, phenols, and tannins in Jatropha curcas, were reported related to stronger inhibition of germination in leaf extract-treated seeds than in stem extract-treated seeds (Tomar et al. 2015).
Those information also support our result that $D$. pentandra leaf extract provided more flavonoid and phenolic compounds than stem extract, which may be responsible for the difference of inhibition level between stem and leaf extracts. Naturally, phenolic and flavonoid accumulation in leaf take a great role in defense mechanisms against herbivores (Kang et al. 2010) and allelopathy mechanism (Xuan et al. 2005).

In conclusion, D. pentandra stem and leaf extracts presented allelopathic activity making them potential for bioherbicide. The mechanisms of action may be related to inhibition of germination and root growth. This is the first report of $D$. pentandra potential as a bioherbicide. However, some plant extracts may affect other plants differently (Radhakrishnan et al. 2018). Therefore, further studies related to greenhouse trial and the metabolism effects of $D$. pentandra on the weeds should be important to provide comprehensive evaluation of $D$. pentandra potential as bioherbicide.

\section{REFERENCES}

Al-Matani S, Wahaibi RNSA, Hossain MA. 2015. In vitro evaluation of the total phenolic and flavonoid contents and the antimicrobial and cytotoxicity activities of crude fruit extracts with different polarities from Ficus sycomorus. Pacific Sci Rev A: Nat Sci Eng 17: 103-108.

Anita A, Khotimah S, Yanti AH. 2014. Aktivitas antibakteri ekstrak daun benalu jambu air (Dendropthoe pentandra (L.) Miq) terhadap pertumbuhan Salmonella typhi. Jurnal Protobiont 3 (2): 268-272. [Indonesian]

Chen F, Liu K, Xie Z, Liu M, Chen C. 2018. Effects of decomposing leaf litter of Leucaena leucocephala on photosynthetic traits of Cynodon dactylon and Medicago sativa. New For 49: 667-679.

Chon SU, Jennings JA, Nelson CJ. 2006. Alfalfa (Medicago sativa L.) autotoxicity : current status. Allelopath J 18 (1): 1-24.

Chuah TS, Tiun SM, Ismail BS. 2011. Allelopathic potential of crops on germination and growth of goosegrass (Eleusine indica L. Gaertn) weed. Allelopathy J 27 (1): 33-42.

Dayan FE, Duke SO. 2014. Natural compounds as next-generation herbicides. Plant Physiol 160: 1090-1105.

Do QD, Angkawijaya AE, Tran-Nguyen PL, Huynh LH, Soetaredjo FE, Ismadji S, Ju YH. 2013. Effect of extraction solvent on total phenol content, total flavonoid content, and antioxidant activity of Limnophila aromatica. J Food Drug Anal 22: 296-302.

Fitrilia T, Bintang M, Safithri M. 2017. Inhibisi enzim $\alpha$-glukosidase menggunakan ekstrak daun benalu cengkeh (Dendrophthoe pentandra (L.) Miq.). Jurnal Agroindustri Halal 3 (1): 41-47. [Indonesian]

Fitrilia T, Bintang M, Safithri M. 2015. Phytochemical screening and antioxidant activity of clove mistletoe leaf extract (Dendrophthoe pentandra (L.) Miq). IOSR J Pharm 5 (8): 13-18.

Gharde Y, Singh PK, Dubey RP, Gupta PK. 2018. Assessment of yield and economic losses in agriculture due to weeds in India. Crop Prot 107: 12-18.

Giesen W, Wulffraat S, Zieren M, Scholten L. 2006. Mangrove: Guidebook for Southeast Asia. Dharmasarn Co., Ltd., Bangkok.

Halimshah S, Ismail BS, Ahmad WJW. 2015. Allelopathic Potential of Leaf and Seed of Mucuna bracteata DC. ex Kurz on Eleusine indica (L.) Gaertn. AIP Conf Proc 1678: 020034-1-020034-6. DOI: $10.1063 / 1.4931219$

Hegab MM, Khodary SEA. Hammouda O, Ghareib HR. 2008. Autotoxicity of chard and its allelopathic potentiality on germination and some metabolic activities associated with growth of wheat seedlings. Afr J Biotechnol 7 (7): 884-892

Joshi R. 2018. Role of enzymes in seed germination. Intl J Creative Res Thoughts 6 (2): 1481-1485.

Kang JH, Liu G, Shi F, Jones AD, Beaudry RM, Howe GA. 2010. The tomato odorless-2 mutant is defective in trichome-based production of diverse specialized metabolites and broad-spectrum resistance to insect herbivores. Plant Physiol 154: 262-272. 
Kanzler A, van Staden J. 1984. Seed germination in goose grass (Eleusine indica). South Afr J Bot 3: 108-110.

Lichter JM, Reid MS, and Berry AM. 1991. New methods for control of leafy mistletoe (Phoradendron spp.) on landscape trees. J Arboricult 17 (5): 127-130.

Madane AN, Patil BJ. 2017. Allelopathic effect of Eupatorium odoratum L. on amylase activity during seed germination of Cicer arietinum $\mathrm{L}$. and Cajanus cajan (L) Millsp. Biosci Discov 8 (1): 82-86.

Maffei HM, Filip GM, Grulke NE, Oblinger BW, Margolis EQ, Chadwick KL. 2016. Pruning high-value Douglas-fir can reduce dwarf mistletoe severity and increase longevity in Central Oregon. For Ecol Manag 379: 11-19.

Mousavi SH, Saeid KHA, Moshatati A. 2013. Effect of leaf, stem and roo extract of alfalfa (Melilotus indicus) on seed germination and seedling growth of wheat (Triticum aestivum). Int J Agric Crop Sci 5 (1): 44 49.

Mukherjee S, Dalal T. 2015. Cytological changes in lentil in response to allelopathic effect of Xanthium strumarium L. Intl J Adv Res 3 (12): 1619-1627.

Ncube NS, Afolayan AJ, Okoh AI. 2008. Assessment techniques of antimicrobial properties of natural compounds of plant origin: current methods and future trends. Afr J Biotechnol 7 (12): 1797-1806.

Othman MR, Leong ST, Bakar B, Awang K, Annuar MSM. 2012. Allelopathic potentials of Cuscuta campestris Juncker extracts on germination and growth of radish (Raphanus sativus L.) and lettuce (Lactuca sativa L.). J Agric Sci 4 (9): 57-63.

Priya US, Neelamegam R. 2016. Evaluation of allelopathic effect of a hemiparasitic mistletoe plant, Dendrophthoe falcata (L.F.) Ettingsh on Oryza sativa and Vigna radiata. Intl J Adv Res Biol Sci 3 (7): 114 121.

Qasem JR. 2011. Herbicides applications: problems and considerations. In: Kortekamp A (ed) Herbicides and Environment. InTech, Rijeka.

Radhakrishnan R, Alqarawi AA, Abd_Allah EF. 2018. Bioherbicides: Current knowledge on weed control mechanism. Ecotoxicol Environ Saf 158: 131-138.

Romman SA. 2016. Differential allelopathic expression of different plant parts of Achillea biebersteinii. Acta Biol Hungarica 67 (2): 159-168.

Sandoval JR, Rodriguez PA. 2014. Eleusine indica (Goose Grass). CABI, Wallingford, UK. https://www.cabi.org/isc/datasheet/20675.

Selvi EK, Turumatay H, Demir A, Turumatay EA. 2018. Phytochemical profiling and evaluation of the hepatoprotective effect of Cuscuta campestris by high-performance liquid chromatography with diode array detection. Anal Lett: 1-15.

Shaikh AC, Gupta A, Chaphalkar SR. 2016. Identification of structurally unique molecules, phytochemical and immunological activity of medicinal plants. International J Med Pharm Res 4 (4): 223-230.
Singh NB, Singh D, Singh A. 2009. Modification of physiological responses of water-stressed Zea mays seedlings by leachate of Nicotiana plumbaginifolia. Gen Appl Plant Physiol 35 (1-2): 51-63.

Soltys D, Langwald AR, Kurek W, Gniazdowska A, Sliwinska E, Bogatek R. 2011. Cyanamide mode of action during inhibition of onion (Allium cepa L.) root growth involves disturbances in cell division and cytoskeleton formation. Planta 234: 609-621.

Sumariono, Widaryanto E, Nugroho A. 2016. Allelopathy test of the lovevine's (Cassytha filiformis L.) extracts as a bioherbicide against seed germination of amaranth (Amaranthus spinosus L.). IOSR J Agric Vet Sci 9 (5): 59-62.

Sunaryo. 2008. Pemarasitan benalu Dendrophthoe pentandra (L.) Miq. pada tanaman koleksi Kebun Raya Cibodas, Jawa Barat. Jurnal Natur Indonesia 11 (1): 48-58. [Indonesian]

Taban A, Saharkhiz MJ. 2015. Natural phytotoxic activity of water extracts and dried leaf powders of three Satureja species. Biocatalysis Agric Biotechnol 4: 594-602.

Teerarak M, Charoenying P, Laosinwattana C. 2012. Physiological and cellular mechanisms of natural herbicide resource from Aglaia odorata Lour. on bioassay plants. Acta Physiol Plant 34 (4): 1277 1285.

Tobe K, Li X, Omasa K. 2000. Seed germination and radicle growth of a halophyte, Kalidium capsicum (Chenopodiaceae). Ann Bot 85 (3): 391-396.

Tomar NS, Sharma M, Agarwal RM. 2015. Phytochemical analysis of Jatropha curcas L. during different seasons and developmental stages and seedling growth of wheat (Triticum aestivum L) as affected by extracts/leachates of Jatropha curcas L. Physiol Mol Biol Plants 21 (1): 83-92.

Watson D. 2018. Final Report: Reconnaissance and Recommendations for Mistletoe Management in Macadamia Orchards. Hort Innovation, Sydney.

Widiyastuti YN, Etikawati, Haryanti S. 2011. Eksplorasi, Identifikasi, dan Uji Sitotoksisitas Tanaman Obat serta Pengembangan Formulanya Sebagai Antikanker Berbasis Etnobotani Medis. Ministry of Health Indonesia, Karanganyar. [Indonesian]

Xuan TD, Tawata S, Khanh TD, Chung IM. 2005. Decomposition of allelopathic plants in soil. J Agron Crop Sci 191: 162-171.

Yee LS, Fauzi NFM, Najihah NN, Daud NM, Sulain MD. 2017. Study of Dendrophthoe pentandra ethyl acetate extract as potential anticancer candidate on safety and toxicity aspects. J Anal Pharm Res 6 (1): 111.

Zaidi MA, Huda A, Crow Jr SA. 2008. Biological activity and elemental composition of Arceuthobium oxycedri (dwarf mistletoe) of juniper forest of Pakistan. Acta Bot Hung 50 (1-2): 223-230.

Zimdahl RL. 2007. Fundamentals of Weed Science. Elsevier, California. 